ACTA AGROBOTANICA

Vol. 62 (2): 173-178

2009

\title{
RELATIONS BETWEEN BOILING WATER TEST, STANDARD GERMINATION TEST AND FIELD EMERGENCE OF LEEK (Allium porrum L.) AND ONION (Allium cepa L.) SEEDS
}

\author{
Ismail Guvenc' ${ }^{1}$, Haluk Caglar Kaymak²*, Sibel Duman² \\ ${ }^{1}$ Safiye Cikrikcioglu Vocational College, Erciyes University, 38039, Kayseri, Turkey \\ ${ }^{2}$ Department of Horticulture, Agriculture Faculty, Atatürk University, 25240, Erzurum, Turkey \\ e-mail: hckaymak@atauni.edu.tr
}

Received: 6.04.2009

\begin{abstract}
The aim of this study was to determine relations occurring between boiling water test, standard germination test and field emergence of leek (Allium porrum L.) and onion (Allium сера $\mathrm{L}$.) seeds. In this study, seeds of six lots ('Kalem', 'Ala', 'Ínegöl-A, B, C and D') from three cultivars of leek and seven onion cultivars ('Early Texas Grano' (ETG), 'Panku', 'Storm', 'Banko', 'Aki', 'Kisagün' and 'Banka') seeds were used as plant material and their viability was evaluated in boiling water test (BWT), standard germination test (SGT) and field emergence (FE). The percentage of field emergence was evaluated at three sowing times: 20 May (FE-I), 10 June (FE-II) and 20 July (FE-III). The mean germination of leek seeds varied from $77.5 \%$ to $100.0 \%$ and from $36.0 \%$ to $61.0 \%$ in SGT and BWT, respectively. While the range of results obtained in the boiling water test was from $38.5 \%$ to $60.0 \%$, the range of results of the standard germination test was from $81.0 \%$ to $100.0 \%$ in onion seeds. The range of field emergence was between $18.5 \%$ ('Kisagün', FE-III) and $72.0 \%$ (İnegöl-C', FE-II). Besides, the boiling water test was correlated highly significantly with SGT (r $=0.670 * *)$, FE-I $(r=0.923 * *)$, FE-II $(r=0.906 * *)$ and FE-III $\left(\mathrm{r}=0.939^{* *}\right)$ in leek seeds. Similarly, BWT showed positive correlation with SGT $\left(\mathrm{r}=0.568^{* *}\right)$, FE-I $(\mathrm{r}=0.844 * *)$, FE-II $\left(\mathrm{r}=0.933^{* *}\right)$ and FE-III $\left(\mathrm{r}=0.858^{* *}\right)$ in onion seeds. In conclusion, the boiling water test is a new and reliable technique to test seed viability and it has a great potential to test rapidly germination and field emergence of leek and onion seeds at different sowing times.
\end{abstract}

Key words: Allium porrum L., Allium cepa L., viability, field emergence, boiling water test

\section{INTRODUCTION}

Numerous tests exist for determining seed viability in vegetable crops. Generally, the standard germination test is accepted as the primary method for determining seed quality. When field conditions at planting are near optimum, the standard germination test correlates well with field emergence ( $\mathrm{H}$ a 11 and W i e s n e r, 1990). The first count of the standard germination test is considered to be a measure of seed vigor (Te Krony and Egli, 1977). Generally, vigor tests have proven to be more useful as predictors of field emergence than the standard germination test (K o l a s in s k a et al. 2000). Regardless of its acceptance, the germination test is merely an estimate and has certain limitations as a universal prediction of seed quality. However, a quick test might be completed only in a few hours, as compared to some germination tests that may require as long as 2 months for some species (Copeland and McDonald, 1985).

Standard germination tests for leek (Allium porrum L.) and onion (Allium cepa L.) seeds are completed within 14 and 12 days, respectively (ISTA 1996). Therefore, sometimes it is essential to determine rapidly seed viability and vigor. The boiling water test can be used as a rapid indicator of onion and leek seed viability in seed lots instead of other time-consuming germination tests ( Guvenc, 2002; Guvenc and Kaymak, 2003; Guvenc and Kaymak, 2004; Guvenc and Kaymak, 2006). However, field emergence in relation to the boiling water test, as a new test, in leek and onion seeds has not been clearly identified. Therefore, the objective of this research was to determine the relations between boiling water test, standard germination test and field emergence of leek and onion seeds at different sowing times.

\section{MATERIALS AND METHODS}

This study was conducted at Ataturk University, Agriculture Faculty, Erzurum, Turkey, during 2005-2006. In this study, seeds of six lots ('Kalem', 'Ala', 'İnegöl-A, B, C and D') from three cultivars of 
leek and seven onion (Allium cepa L.) cultivars ('Early Texas Grano' (ETG), 'Panku', 'Storm', 'Banko', 'Aki', 'Kisagün' and 'Banka') seeds were used as plant material. All studied seeds were supplied by Turkish seed companies.

The principle of Boiling Water Test (BWT) is based on the evaluation of radicle protrusion from the seeds immersed to boiling water for certain time (Guvenc, 2002; Guvenc and Kaymak, 2003; Guvenc and Kaymak, 2004; Guvenc and $\mathrm{K}$ a y mak, 2006). Leek seeds of each cultivar were immersed into boiling water in a glass container (a beaker), and then they were monitored for protrusion at 10-minute intervals during boiling up to 60 minutes. During boiling, the protruded seeds were counted and removed. Seeds having protruded radicles were recorded as viable. The boiling water test was conducted using four replicates of 50 seeds per leek and onion cultivar.

The standard germination test (SGT) was conducted using four replicates of 50 seeds from each cultivar. The seeds were incubated in $9 \mathrm{~cm}$ Petri dishes between two filter papers saturated with water containing Benlate (50\% benomyl) $1 \mathrm{~g} \mathrm{l}^{-1}$ to prevent fungal growth at $20^{\circ} \mathrm{C}$ (ISTA 1996). Visible-radicle protrusion was the criterion of germination. Germinated seeds were recorded and discarded at $24 \mathrm{~h}$ intervals during 14 days. The results were expressed as final germination percentage ( $\mathrm{Guve} \mathrm{n} \mathrm{c}, 2002 ; \mathrm{Gu}$ ve n c and $\mathrm{Kaymak}, 2003$; Kay mak et al. 2004; Guven c and Kaymak, 2006).

To assess field emergence (FE), seeds from each sample were sown $1 \mathrm{~cm}$ deep by hand on four replicated plots (Guvenc and Kaymak, 2003). All samples were sown at three sowing dates (20 May (FE-I), 10 June (FE-II) and 20 July (FE-III) in loamy soil and irrigated with mini springs daily. Field emergence was conducted using four replicates of 50 seeds from each cultivar. The number of emerged seedlings was counted daily until no further seedlings appeared. The experimental area (Erzurum) is located at $40^{\circ} 57^{\prime}$ and $39^{\circ} 10^{\prime} \mathrm{N}$ latitude, $40^{\circ} 15^{\prime}$ and $42^{\circ} 35^{\prime} \mathrm{E}$ longitude, $1850 \mathrm{~m}$ above sea level in northeastern Turkey.

The laboratory and field experiments were conducted as randomized complete block designs, with each treatment replicated four times. The data obtained in this study were subjected to ANOVA and the differences between means were compared using Duncan's multiple range test. Besides, correlation coefficients between compared tests (r) were also determined.

\section{RESULTS AND DISCUSSION}

The results obtained in the viability tests are presented in Table 1 . The mean value of viability of leek and onion seeds varied, depending on cultivar and test method. As seen in Table 1, the lowest values of leek seed viability were determined for 'İnegöl-B' in both the boiling water test and standard germination test, $36.0 \%$ and $77.5 \%$ respectively. The seeds of other leek cultivars germinated $100 \%$ in the standard germination test. Among the studied leek cultivars, the seeds of 'Inegöl-C' had the highest viability in the boiling water test $(61 \%)$.

Similar results were obtained in the tests with onion seeds and the lowest values were determined in 'Panku' seeds in both the boiling water test and standard germination test. While the range of results obtained in the standard germination test was between $81 \%$ ('Panku') and $100 \%$ (all cultivars except 'Panku' and 'Banka'), the results of boiling water test ranged from $38.5 \%$ ('Panku') to $60.0 \%$ ('Aki'). Generally, the determined viability values for leek and onion seeds in the boiling water test were lower than those of the standard germination test (Tab. 1). This might be attributed to differences between the test methods and also between viability levels of seeds ( $\mathrm{Guvenc}$, 2002; Guvenc and Kaymak, 2003; Guvenc and Kaymak, 2004; Guvenc and Kaymak, 2006). The poor vigor of some seed lots could have been due to improper harvesting and handling, poor storage conditions and some other factors reducing seed quality (Waters and Blanchette, 1983). The viability of leek and onion seeds determined with the boiling water test had a significantly positive correlation with the standard germination test (Tabs 4,5$)$. These results agree with similar studies on leek and onion seeds (Guvenc, 2002; Guvenc and Kaymak, 2003; Guvenc and Kaymak, 2004; Guvenc and $\mathrm{K}$ a y $\mathrm{m}$ a k, 2006).

Data for the different sowing dates illustrating field emergence of leek and onion seeds are presented in Table 2. The mean value of emergence of leek and onion seeds varied in dependence on cultivar and sowing date. Early and delayed sowings decreased field emergence of both leek and onion seeds. Delaying sowing affected field emergence more negatively than early sowing (Tab. 2). Higher emergence rates were observed at the second sowing time (FE-2). Among the leek cultivars, seeds of 'İnegöl-B' had the lowest field emergence ratios in FE-I, II and III, 30.5\%, 34.5\% and $24.0 \%$, respectively, seeds of 'İnegöl-C' had the highest field emergence ratios in FE-I, II and III, 64.5\%, $72.0 \%$ and $44.0 \%$, respectively. The field emergence values of onion seeds ranged in dependence on cultivars between 26.0\% ('Banka', FE-III) and 69.0\% ('Banko', FE-II). In a similar research study, it was found that average emergence values of leek seeds ranged from $21 \%$ to $91 \%$ and they were also dependent on the cultivar (Guvenc and Kaymak, 2003). Besides, it 
Table 1

Mean values of boiling water test (BWT) and standard germination test (SGT) of seeds of studied leek and onion seeds.

\begin{tabular}{|c|c|c|c|}
\hline & Cultivars & BWT (\%) & SGT (\%) \\
\hline \multirow{6}{*}{ Leek } & İnegöl-A & $51.0 \mathrm{~b}$ & $100.0 \mathrm{a}$ \\
\hline & İnegöl-B & $36.0 \mathrm{~d}$ & $77.5 \mathrm{~b}$ \\
\hline & İnegöl-C & $61.0 \mathrm{a}$ & $100.0 \mathrm{a}$ \\
\hline & İnegöl-D & $58.5 \mathrm{a}$ & $100.0 \mathrm{a}$ \\
\hline & Kalem & $44.5 \mathrm{c}$ & $100.0 \mathrm{a}$ \\
\hline & Ala & $44.0 \mathrm{c}$ & $100.0 \mathrm{a}$ \\
\hline \multirow{7}{*}{ Onion } & TEG & $50.0 \mathrm{~b}$ & $100.0 \mathrm{a}$ \\
\hline & Panku & $38.5 \mathrm{e}$ & $81.0 \mathrm{c}$ \\
\hline & Storm & $44.5 \mathrm{c}$ & $100.0 \mathrm{a}$ \\
\hline & Banko & $59.0 \mathrm{a}$ & $100.0 \mathrm{a}$ \\
\hline & Aki & $60.0 \mathrm{a}$ & $100.0 \mathrm{a}$ \\
\hline & Kisagün & $40.0 \mathrm{de}$ & $100.0 \mathrm{a}$ \\
\hline & Banka & $42.5 \mathrm{~cd}$ & $83.0 \mathrm{~b}$ \\
\hline
\end{tabular}

Different letters denote significant differences between cultivars at $\mathrm{P}<0.01$.

Table 2

Field emergence of seeds (in \%) of studied leek and onion cultivars in dependence on time of sowing.

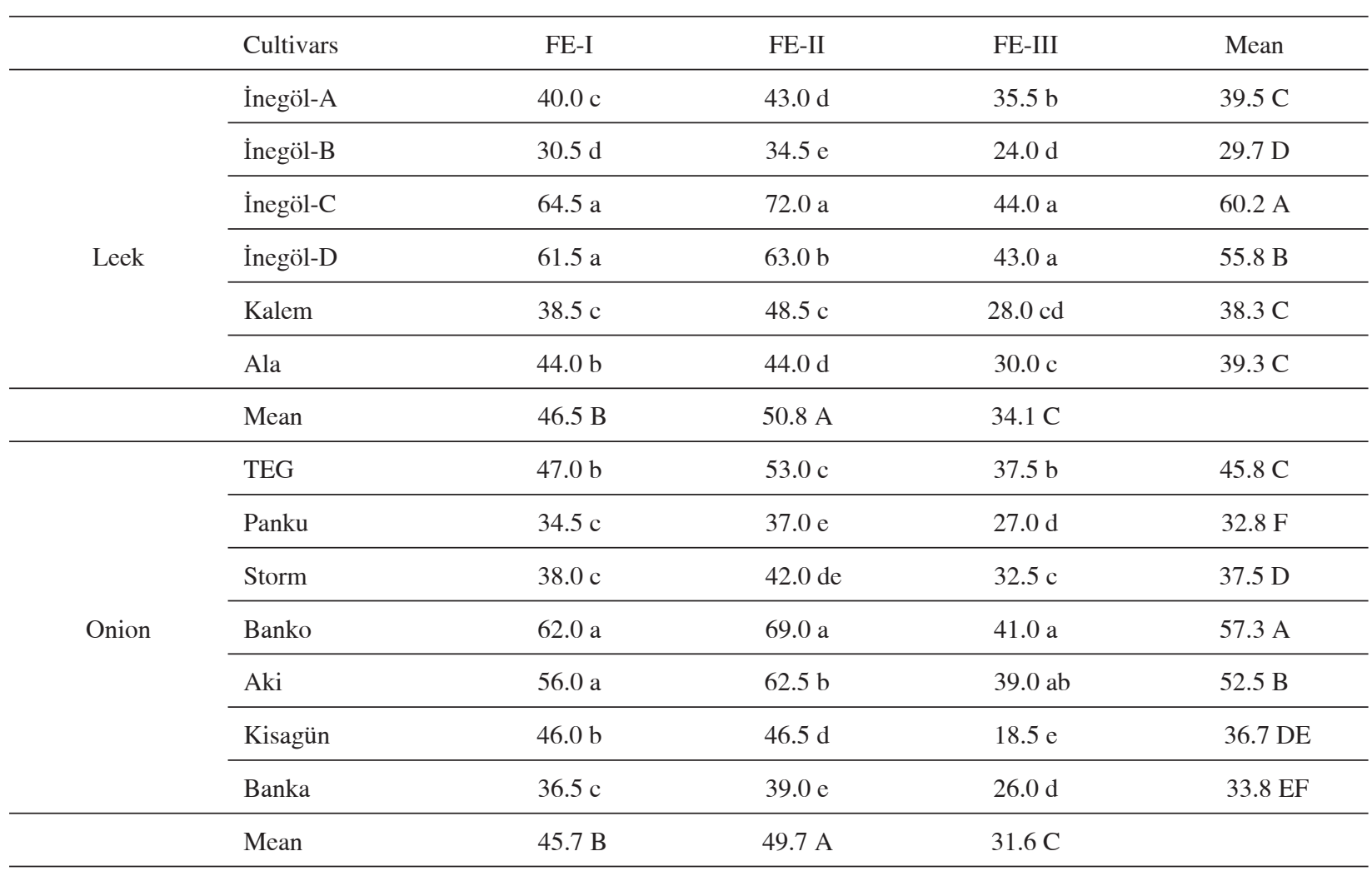

Different letters denote significant differences at $\mathrm{P}<0.01$. 
was noted that environmental factors influenced significantly field emergence, with soil temperature on the day of sowing being most evident ( $\mathrm{K}$ o l a s i n s k a et al. 2000; K a y mak and Guve n c, 2008). The differences observed in this experiment were probably associated with differences in soil temperature at seed sowing and also with cultivar characteristics.

The analysis of variance showed significant differences in field emergence of the studied seeds in dependence on cultivar and sowing date (Tabs 2, $3)$. The interactions between cultivars and sowing dates were significant for field emergence with respect to both leek and onion seeds. These interactions demonstrated that the effect of sowing date on field emergence varied considerably in dependence on cultivar or that field emergence was affected by the performance of the cultivar under different sowing dates.

Table 3

Interactions between cultivar and sowing date.

\begin{tabular}{lcc}
\hline & \multicolumn{2}{c}{ F values } \\
\hline Source of variation & Leek & Field emergence \\
\hline Cultivar (C) & $406.565^{* *}$ & Onion \\
\hline Sowing Date (SD) & $451.424^{* *}$ & $161.055^{* *}$ \\
\hline C x SD & $18.594^{* * *}$ & $363.686^{* *}$ \\
\hline
\end{tabular}

** Significant at $P<0.01 \%$ level

Table 4

Cumulative correlation coefficients (r) between boiling water test, standard germination test and field emergence of leek seeds.

\begin{tabular}{cccccc}
\hline & BWT & SGT & FE-I & FE-II & FE-III \\
\hline BWT & 1.000 & & & \\
\hline SGT & $0.670^{* *}$ & & & \\
\hline FE-I & $0.923^{* *}$ & $0.572^{* *}$ & & \\
\hline FE-II & $0.906^{* *}$ & $0.568^{* *}$ & $0.945^{* *}$ & $0.861^{* *}$ & 1.000 \\
\hline FE-III & $0.939^{* *}$ & $0.585^{* *}$ & $0.904^{* *}$ & & \\
\hline
\end{tabular}

** Significant at $P<0.01 \%$ level

Table 5

Cumulative correlation coefficients (r) between boiling water test, standard germination test and field emergence of onion seeds.

\begin{tabular}{|c|c|c|c|c|c|}
\hline & BWT & SGT & FE-I & FE-II & FE-III \\
\hline BWT & 1.000 & & & & \\
\hline SGT & $0.568 * *$ & & & & \\
\hline FE-I & $0.844 * *$ & $0.646 * *$ & & & \\
\hline FE-II & $0.933 * *$ & $0.641 * *$ & $0.926 * *$ & & \\
\hline FE-III & $0.858 * *$ & $0.417 * *$ & $0.622 * *$ & $0.748 * *$ & 1.000 \\
\hline
\end{tabular}

** Significant at $P<0.01 \%$ level 
Correlation coefficients (r) among boiling water test, standard germination test and field emergence of seeds of the studied leek and onion cultivars are presented in Table 4 and 5, respectively. The boiling water test was highly significantly correlated with SGT $(\mathrm{r}=0.670 * *)$, FE-I $(\mathrm{r}=0.923 * *)$, FE-II $\left(\mathrm{r}=0.906^{* *}\right)$ and FE-III $\left(\mathrm{r}=0.939^{* *}\right)$ in leek seeds. Similarly, BWT showed a positive and high correlation with SGT $(\mathrm{r}=0.568 * *)$, FE-I $(\mathrm{r}=0.844 * *)$, FEII $(\mathrm{r}=0.933 * *)$ and FE-III $(\mathrm{r}=0.858 * *)$ in onion seeds. In other words, the boiling water test correlated well and positively with the standard germination test and field emergence of both leek and onion seeds (Tabs 4, 5).

The time of BWT was considerably short $\left(1 \mathrm{~h} \mathrm{sample} \mathrm{s}^{-1}\right)$. Therefore, BWT seems to be a suitable method for rapid assessment of viability and field emergence in leek and onion seeds. Also, as mentioned by Guvenc (2002), Guvenc and Kaymak, (2003) and (2004) this rapid method has been found to be a reliable technique for prediction of viability and field emergence of leek and onion seeds used in the study.

\section{CONCLUSIONS}

According to the results of this research, it might be assessed that the boiling water test could be used as a rapid and simple method to measure seed viability and field emergence by evaluating radicle protrusion of leek and onion seeds in boiling water. Furthermore, this test is easy to standardize among laboratories tests compared to the standard germination test and field emergence at different sowing dates and it does not require any special equipment and/or expertise. In conclusion, the boiling water test is a new and reliable technique to test viability of leek and onion seeds, and can be used as an indicator of seed emergence in field cultivation of leek and onion.

\section{REFERENCES}

Copeland L. O., McDonald M. B., 1985. Principle of seed science and technology (Second edition). Macmillan Publishing Company, New York, US: 321.

Guvenc I., 2002. Prediction of viability of onion (Allium сера) seeds by boiling water test. Indian J. Agric. Sci. 72 (2): 111-2.

Guvenc I., Kay mak H. C., 2003. Prediction of viability of leek (Allium porrum) seeds by a new test. Acta Agrobot. 56 (1-2): 21-25.

Guvenc I., Kay mak H. C., 2004. Prediction of viability of onion (Allium cepa L.) seeds in different size by a rapid method. V National Symposium on Vegetable Growing, Canakkale, 21-24 September: 96-100.
Guvenc, I., Kaymak, H. C., 2006. Suitability of boiling water test in prediction of seed viability of leek (Allium porrum) seeds. Indian J. Agric. Sci. 76 (7): 435-437.

Hall R. D., Wiesner L. E., 1990. Relationship between seed vigor test and field performance of regar meadow bromegrass. Crop Science. 30 (5): 967-70.

I S T A . 1996. International for seed testing rules. International Seed Testing Association, Zurich, Switzerland.

Kaymak H. C., Guvenc I., Dursun A., 2004. Determination of viability and some quality properties of radish (Raphanus sativus L.) seeds. V National Symposium on Vegetable Growing, Canakkale, 21-24 September: 359363.

Kay mak H. C., Guven c I., 2008. Determine the Relations between Field Emergence with Laboratory Tests and Physical Properties of Fresh Bean (Phaseolus vulgaris L.) Seeds. Alatarim, 7 (1): 36-43.

Kolas inska K., Szyrmer J., Dul S., 2000. Relationship between laboratory seed quality tests and field emergence of common bean seed. Crop Science, 40: 470-475.

TeKrony D. M., Egli D. B., 1977. Relationship between laboratory indices of soybean seed vigor and field emergence. Crop Science, 17: 573-577.

Waters L. Jr., B la nchette B. L., 1983. Prediction of sweet corn field emergence by conductivity and cold tests. J. Amer. Soc. Hort. Sci. 108: 778-781.

\section{Relacje pomiędzy testem wrzącej wody, standardowym testem kiełkowania oraz polową zdolnością wschodów pora (Allium porrum L.) i cebuli zwyczajnej (Allium cepa $\mathrm{L}$ ).}

\section{Streszczenie}

Celem pracy było określenie zależności zachodzących pomiędzy standardowym testem kiełkowania oraz polową zdolnością wschodów pora (Allium porrum L.) i cebuli zwyczajnej (Allium cepa L). Jako materiał roślinny posłużyło 6 prób nasion trzech odmian pora ('Kalem', 'Ala', 'İnegól-A, B, C i D') oraz nasiona siedmiu odmian cebuli zwyczajnej ('Early Teras Grano' (ETG), 'Panku', 'Storm', 'Banko', 'Aki', 'Kisagün' i 'Banka'). Żywotność nasion określano stosując test wrzącej wody (BWT ang. boiling water test), standardowy test kiełkowania (ang. SGT standard germination test) oraz polową zdolność wschodów (FE ang. field emergence). Polową zdolność wschodów określano dla trzech terminów wysiewu: 20 maja (FEI), 10 czerwca (FE-II) oraz 20 lipca (Fe-III). Dla nasion pora średnia wartość uzyskana w standardowym teście kiełkowania oraz teście wrzącej wody zmieniała się odpowiednio w zakresie od 77,5 do $100 \%$ oraz od 36,0 do $61,0 \%$. Natomiast dla nasion cebuli wartości uzyskane w teście wrzącej wody i standardowym teście kiełkowania zawierały się odpowiednio w zakresie od 
38,5 do $60,0 \%$ oraz od 81,0 do $100 \%$. Polowa wartość wschodów zawierała się zakresie 18,5\% ('Kisagün', FE-III ) oraz 72,5\% ('İnegól-C', FE-II). U pora zaznaczyła się wysoka korelacja pomiędzy testem wrzącej wody i standardowym testem kiełkowania (SGT) ( $\mathrm{r}=$ $0,670 * *)$, FE-I $(\mathrm{r}=0,923 * *)$, Fe II $\left(\mathrm{r}=0,906^{* *}\right)$ i FEIII $(\mathrm{r}=0,939 * *)$. Również $\mathrm{w}$ przypadku nasion cebuli zaznaczyła się pozytywna korelacja pomiędzy testem wrzącej wody i standardowym testem kiełkowania ( $\mathrm{r}=$ $0,568 * *)$, FE-I $(\mathrm{r}=0.844 * *)$, FE-II $(\mathrm{r}=0,993)$ i FEIII $\left(\mathrm{r}=0.858^{* *}\right)$. Podsumowując należy stwierdzić, że test wrzącej wody może być uznany za nowoczesną i wiarygodną technikę do określania żywotności nasion cebuli i pora i może posłużyć jako wskaźnik do oceny zdolności kiełkowania w uprawie polowej tych roślin w różnych terminach wysiewu. 